\title{
Koulu vuonna 2020
}

Maamme koulutusjärjestelmä menestyy kansainvälisessä vertailussa. Pitkän peruskoulutuksen lisäksi jokaisella nuorella on mahdollisuus suorittaa ammatillinen tutkinto keskiasteella tai korkeakoulussa. Mahdollisuudet opiskeluun aikuisiässä laajenevat merkittävästi. Koulutukseen pääsy ei riipu sosiaalisesta asemasta tai asuinpaikasta.

Koulun tulee kuitenkin uudistua jatkuvasti. Uudistumisen suunnan määräävät tulevaịsuuden tarpeet. On paikallaan arvioida tulevaisuuden koulua - esimerkiksi vuoden 2020 - jo nyt.

\section{Koulu oppilasta - ei oppilaat koulua varten}

Jatkuvan koulutuksen periaatteen toteuttaminen muuttaa oppilaan ja koulun keskinäisen suhteen. Nykyisin koulu valitsee oppilaat ja valinnan jälkeen oppilas on koulun hallinnassa. Tulevaisuudessa oppilas valitsee koulun. Koulu on palvelulaitos, joka järjestää opetusta tarpeen mukaan.

Opiskelu perustuu modulijärjestelmään. Oppilas kokoaa haluamiaan koulutuskokonaisuuksia eli moduleja eri oppilaitoksista haluamanaan ajankohtana. Varsinkin peruskoulun jälkeisessä koulutuksessa työ ja koulutuskokonaisuuksien suorittaminen vuorottelevat tai ovat rinnakkaisia. Tähdätessään tiettyyn tutkintoon oppilas ei ole sidoksissa tiettyyn vuosikurssiin tai edes tiettyyn yhteen oppilaitokseen.

Kuvio 1. Kiinteämuotoinen opintojärjestelmä. Nykyinen peruskoulutus on kiinteämuotoista, jossa opinnot suoritetaan laajoina tutkintoina, yhtäjaksoisesti ja yhdessä oppilaitoksessa. Tutkintojen sisällä valinnaisuus on vähäistä.

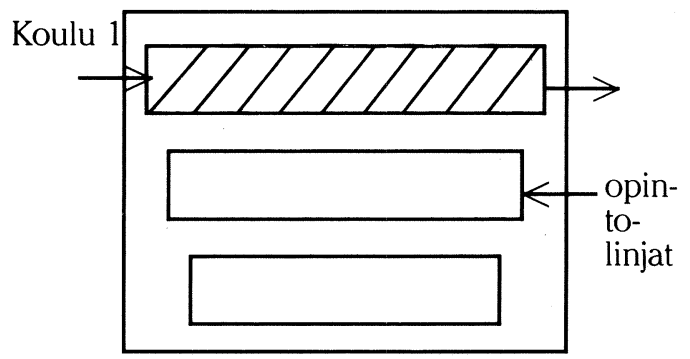

Kuvio 2. Jatkuvan koulutuksen opintojärjestelmä.

Tuleva koulutus koostuu opintokokonaisuuksista (moduleista), joista voidaan vapaasti koota tutkintoja. Opintokokonaisuuksia voidaan koota eri oppilaitoksista, niitä voidaan suorittaa vaihtoehtoisin oppimismenettelyin ja haluttuna ajankohtana. Opintokokonaisuuksia voi suorittaa myös täydennyskoulutuksena.

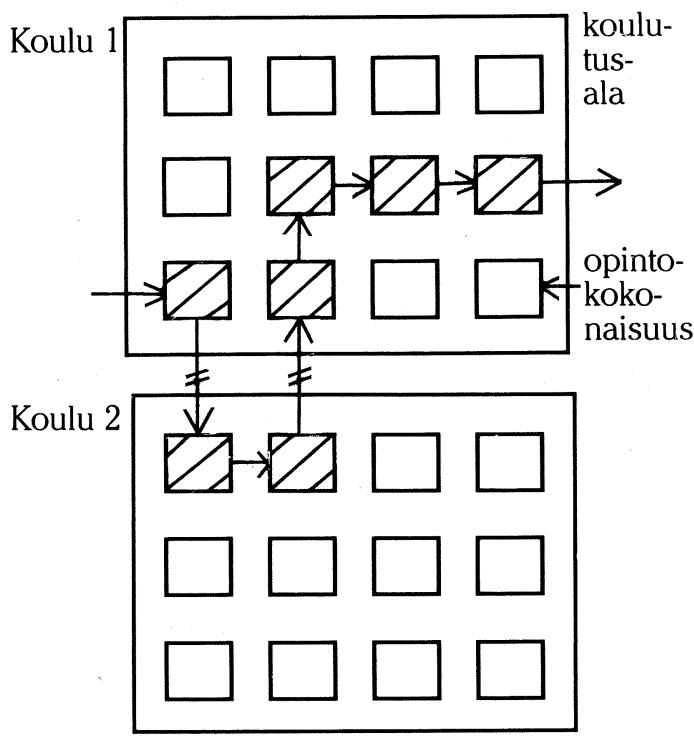

Tutkintoa suoritettaessa perinteistä päiväkoulua käydään ehkä vain muutama kuukausi. Opintokokonaisuudet suoritetaan itseopiskellen, korvaamalla opintosuoritus työkokemuksella tai käymällä iltakoulua. Oppimistapojen monimuotoisuus ja vaihtoehtoisuus ovat jatkuvan koulutuksen järjestelmän edellytys.

Tulevaisuuden koulu antaa mahdollisuuden yksinopiskeluun. Mutta yleensä opiskelu pahtuu ryhmissä. Ryhmissä opiskelevat ovat koulutus- ja työkokemustaustaltaan usein erilaisia. Tällöin ryhmäopiskelu antaa enemmän kuin jos kaikki ryhmät jäsenet olisivat saman koulutustaustan omaavia saman vuosikurssin oppilaita.

Tutkintoon tähtäävän koulutuksen ja täydennyskoulutuksen välillä ei ole selvää rajaa. Suorittamalla koulutuskokonaisuus täydennyskoulutusmielessä, voi oppilas mahdollisesti sisällyttää suorittamansa opinnot laajempaan tut- 
kintokokonaisuuteen. Myös harrastustavoitteisen ja ammattitavoitteisen opiskelun välinen raja hämärtyy. Taide- ja kulttuuripainotteisia opintoja oppilas voi suorittaa halutessaan ja sisällyttää niitä myös ammatilliseen tutkintoonsa.

\section{Koulu osa yhteiskuntaa}

Koulun ja sen ympäristön vuorovaikutus on tiivistä ja jatkuvaa. Koulut tukevat alueensa ja alojensa yritysten kehitystä kouluttamalla sekä uutta henkilöstöä että jo työelämässä toimivia. Eri asteiset oppilaitokset ja yritykset sekä näitä vastaavat muut organisaatiot toteuttavat yhteistyössä kokeilu- ja tutkimusprojekteja. Tämä takaa uusimman tiedon hyväksikäytön niin työssä kuin koulutuksessakin.

Tulevaisuuden koulussa on päätoimisia opettajia vähän. Opettajat tulevat tutkimuslaitoksista, teollisuudesta ja virastoista. He opettavat oman toimensa ohella. Se lisää osaltaan koulun ja sen ympäristön välistä vuorovaikutusta. Kysymyksessä on vastaava opetustyön uudelleenorganisointi ja rakennemuutos kuin mitä on tapahtumassa nyt monissa ammattiryhmissä.

\section{Yksinkertainen koulutusrakenne}

Oppivelvollisuuskoulua tarvitaan myös tulevaisuudessa. Peruskoulussa opitaan periaatteessa samoja asioita kuin nytkin. Niin oppiaineisiin kuin oppimismenetelmiin on mahdollista luoda vaihtoehtoja. Yksittäisten koulujen ei tarvitse olla toistensa jäljitelmiä, vaan persoonallisia sivistysyksiköitä. Opetuksessa ja oppimisessa painottuvat joka tapauksessa tiedon sijasta taidot. Kieltenoppimisessa siirrytään viestintätaitojen omaksumiseen. Samalla tavoin kuvaamataidon korvaa kuvallinen viestintä. Matematiikan sijasta opitaan loogista ajattelua, asiakokonaisuuksien jäsentämistä ja mallintamista. Samoin tiedon hallinta ja käsittely ovat keskeisiä.

Peruskoulun jälkeen nuoret siirtyvät joko suoraan, työssä olon jälkeen tai työssäolon ohella keskiasteen koulutukseen. Tulevaisuudessa keskiaste voisi olla yhtenäinen, jakoa yleissivistävään ja ammatilliseen koulutukseen ei ole. Tällöin osa opintolinjoista voisi painottua ammatillisesti, osa teoreettisesti ja osa taiteellisesti.

Keskiasteen koulutuksen jälkeen on käytännössä kaikilla halukkailla mahdollisuus siirtyä korkeakouluun. Korkeakoulujen koulutustehtävä on tuottaa tieteellisesti koulutettuja ammattilaisia. Opiskelussa ja tutkimuksessa korostuvat erityisesti kansainvälisyys. Suomalaiset opiskelevat ulkomailla. Ulkomaiset opiskelijat ja tutkijat tulevat Suomeen perehtyäkseen suomalaisen tieteen saavutuksiin. Opetus toteutetaan suureksi osaksi vieraalla kielellä.
Peruskoulutuksen jälkeen mennään jatkokoulutukseen sekä hankitaan täydennyskoulutusta. Opiskelu ajoittuu yli koko elämänkaaren. Koulutus on jatkuvaa eikä rajaa nuoruusiän ja aikuiskoulutuksen välillä ole. Toisin sanottuna peruskoulun jälkeisen koulutuksen ja myös joidenkin peruskoulun opintokokonaisuuksien osalta koko koulutusjärjestelmä on kaikkien väestöryhmien ja samalla myös ikäryhmien käytettävissä.

\section{Suomi 2020}

Tulevaisuuden koulu perustuu kuvaan tulevaisuuden Suomesta, sen jo nähtävissä oleville piirteille. Tietomme tulevaisuuden yhteiskunnasta on pakostakin yleisellä tasolla. Myös visio tulevaisuuden koulusta on karkea luonnos.

Tulevaisuuden Suomessa demokratian kehittämisen painopiste siirtyy kaikille samanlaisten perusoikeuksien luomisesta jokaisen yksilön erilaisten tarpeiden tyydyttämiseen. Kasvatus uuteen demokratiaan ja uusi demokratia alkaa koulusta.

Työ tulee säilymään keskeisenä tulevaisuudenkin Suomessa. Työn määrä henkeä kohti kuitenkin vähenee. Kulttuuritoimintojen osuus kasvaa voimakkaasti, olipa kysymys vapaa-ajan harrastetoiminnoista tai taide- ja muusta kulttuuritoiminnasta.

Tieto lisääntyy, arkipäiväisetkin toiminnot yhä teknologistuvat, ihmisten välinen kanssakäyminen monipuolistuu viestintäteknologian kehityksen myötä. Kansainvälisyys on tulevaisuudessa arkipäivää. Tietoa tulee osata hankkia ja käsitellä. Tulevaisuuden kansalaisen perusvalmiuksiin sisältyy taito käsitellä teknisiä apuvälineitä sekä kyky omaksua vieraita kieliä ja kulttuureja.

Työelämässä työnjako muuttuu, hierarkkiatasot vähenevät. Etenkin työnjohtotaso häviää. Työntekijät ryhtyvät johtaman itseään ja suunnittelemaan töitään. Työläisten, toimihenkilöiden ja yrittäjien välinen ero kaventuu. Tulevaisuuden työelämä uudistuu jatkuvasti. Muutos koskee tuotantorakenteita, yksittäisiä organisaatioita ja yksittäisen työntekijän tehtäviä. Kaikilta edellytetään laaja-alaista osaamista, luovuutta, joustavuutta, itsenäisyyttä ja vastuuta.

Koulutus tulee keskeiseksi osaksi tuotannon ja työn kehittämistä. Kun nyt liitämme koulun painotetusti lapsiin ja nuoriin, vastaisuudessa työelämästä käsin kouluttautuminen on koulutusaikana ja oppilasmäärinä laskettuna huomattavasti laajempaa. Myös huomattava osa nykyisestä päiväkoulussa tapahtuvasta nuoruusiän koulutuksesta muuntuu koulutukseksi, jossa opiskelu toteutetaan työelämästä käsin. Nuoruusiän ja aikuiskoulutuksen välinen raja hälvenee. 